\title{
Adolescencja jako permanentny kryzys. Filmoterapeutyczna analiza serialu Ania, nie Anna
}

\section{Abstrakt:}

Ania z Zielonego Wzgórza (1908) autorstwa Lucy Maud Montgomery jest wierną towarzyszką dorastania wielu pokoleń kobiet. Ze względu na umiejscowienie akcji w latach 70. i 80. XIX wieku oraz moment, w którym powieść powstawała (początek XX stulecia), treść utworu może się dzisiaj wydawać anachroniczna. Na przestrzeni lat podejmowano liczne próby przeniesienia tej historii z literackiego oryginału na kinowy i telewizyjny ekran, jednak dopiero serial Moiry Walley-Beckett Ania, nie Anna (2017- ), wyprodukowany oryginalnie dla kanadyjskiej publicznej stacji telewizyjnej CBC i dystrybuowany szeroko na platformie Netflix, nadał dziełu życia Montgomery współczesny wymiar. W tekście poddano analizie poszczególne elementy serialu pod kątem wykorzystania jego potencjału w terapeutycznej pracy z młodzieżą. Rozważaniom towarzyszą kontekstualne odniesienia do ogólnego modelu rozwoju tożsamości autorstwa Hanny Liberskiej oraz teorii filmoterapeutycznej Małgorzaty Kozubek.

\section{Słowa kluczowe:}

adaptacja, Ania, nie Anna, Ania z Zielonego Wzgórza, dorastanie, filmoterapia, Lucy Maud Montgomery, Moira Walley-Beckett, powieść dla dziewcząt, serial młodzieżowy, upodmiotowienie

\section{Adolescence as a Permanent Crisis: A Cinematherapeutic Analysis of Anne with an $E$}

\section{Abstract:}

For many generations of women, Lucy Maud Montgomery's Anne of Green Gables (1908) has been a faithful companion in the process of coming of age. Nevertheless, when judged solely by its setting and timeframe (1870s and 1880s), and the moment of its publication (the beginning of the $20^{\text {th }}$ century), the book might appear somewhat anachronic. Several attempts at bringing Anne's story to life on both the big

* Karolina Gierszewska - przygotowuje pracę licencjacką w Instytucie Kulturoznawstwa na Wydziale Nauk Historycznych i Pedagogicznych Uniwersytetu Wrocławskiego dotyczącą wizerunku czarnoskórych kobiet w serialach Shondy Rhimes. Kontakt: karolina.agata.gierszewska@gmail.com. 
and small screen have been made, but only one of them - Moira Walley-Beckett's Anne with an E (2017-Present), produced for Canadian public network CBC and widely distributed by Netflix - can be said to have captured the novel's spirit by reembedding it in a truly modern context. The main goal of this paper is to analyse various elements of Walley-Beckett's take on Montgomery's opus with regard to their potential usefulness in therapeutic practice with young adults. The reflections made in the article are accompanied by contextual references to Hanna Liberska's general model of identity development and Małgorzata Kozubek's theory of cinema therapy.

\section{Key words:}

adaptation, Anne with an E, Anne of Green Gables, adolescence, cinema therapy, Lucy Maud Montgomery, Moira Walley-Beckett, novel for girls, young adult TV series, empowerment

\section{Wprowadzenie}

W powieści Lucy Maud Montgomery (1908/2014) dwunastoletnia Ania ${ }^{1}$ Shirley, po latach spędzonych w przytułkach dla sierot oraz rodzinach zastępczych, trafia do Avonlea, niewielkiej osady na Wyspie Księcia Edwarda. To tam, na farmie Zielone Wzgórze, pod opieką nowych opiekunów - rodzeństwa Maryli i Mateusza Cuthbertów - znajduje wreszcie ciepły, kochający dom. Losy Ani na pozór są dobrą podstawą do terapii z osobami, którym nieobce są problemy związane z brakiem rodziny i koniecznością zdefiniowania swojej wykorzenionej tożsamości. Niewykluczone, że optymistyczny w wymowie oryginał literacki oraz najpopularniejsza dotychczas ekranizacja, miniserial w reżyserii Kevina Sullivana (McDougall, Sullivan, 1985), odegrałyby istotną rolę w tym procesie; tego samego nie można jednak powiedzieć o najnowszej telewizyjnej adaptacji Ani z Zielonego Wzgórza - serialu Ania, nie Anna² pomysłu Moiry Walley-Beckett (2017- ), który oryginalnie dystrybuowała kanadyjska stacja CBC. Współczesna wersja opowieści wpisuje się w tożsamościowe

1 W artykule stosowane są imiona bohaterów i nazwy, które zakorzeniły się w kulturze polskiej wskutek popularności przekładu Rozalii Bernsteinowej i były stosowane także przez wielu późniejszych tłumaczy prozy o Ani Shirley. Na temat przekładów powieści Montgomery na język polski i ich obecności w rodzimej świadomości kulturowej pisali m.in. Piotr Oczko, Tomasz Nastulczyk i Dorota Powieśnik (2018).

2 Jak podaje portal CBC (2016), w Kanadzie serial dystrybuowany jest jako Anne, natomiast międzynarodowa dystrybucja Netflixa zmieniła oryginalny tytuł na Anne with an E. 
i dydaktyczne trendy widoczne na przestrzeni ostatnich lat w utworach kultury popularnej kierowanych do grupy tzw. młodych dorosłych ${ }^{3}$. Uwspółcześnienie literackiego pierwowzoru w duchu tendencji wiodących w obszarze twórczości przeznaczonej dla young adults wiązało się z podjęciem problematyki, która oryginalnie nie mogła zostać poruszona w powieści ze względu na czas zarówno jej powstania, jak i akcji utworu. Sposób budowania narracji w serialu pozwala również inaczej zwrócić się do hipotetycznego odbiorcy i tym samym nadać aktualny wydźwięk treściom, których dotychczasowa forma $\mathrm{z}$ biegiem czasu zdążyła się już zdezaktualizować (Has-Tokarz, 2006/2007, s. 89).

Serial, wykupiony i dystrybuowany poza Kanadą przez platformę streamingową Netflix, mimo zakorzenienia w oryginalnej historii przedstawia losy Ani Shirley w zupełnie inny sposób niż dzieło Montgomery. Ania, nie Anna to pogłębiony psychologicznie portret głównej bohaterki, w którym na pierwszy plan wysuwa się trauma dziecka - odrzuconego, niechcianego, niepotrafiącego dopasować się do otaczających realiów (Oczko, Nastulczyk, Powieśnik, 2018, s. 264). Zachowania będące wynikiem doznanej krzywdy, choć w powieści oraz wspomnianej ekranizacji Sullivana również są ukazywane, to w najnowszym serialu ulegają intensyfikacji i bardzo mocno rzutują na sposób, w jaki Ania buduje swoje relacje ze światem, w którym żyje. O ile we wcześniejszych, przywołanych wyżej wersjach tej opowieści odseparowanie bohaterki od rzeczywistości przedstawiane było jako interesujący rys osobowościowy, o tyle Ania w 2017 roku (i później) jest przede wszystkim bardzo skrzywdzonym dzieckiem, dla którego pobyt na Zielonym Wzgórzu wydaje się pierwszą ważną terapią - jeśli można o niej w ogóle mówić w realiach kanadyjskiej wsi drugiej połowy XIX wieku.

Celem niniejszego artykułu jest przeprowadzenie filmoterapeutycznej analizy serialu Walley-Beckett w oparciu o założenia teoretyczne zaprezentowane

\footnotetext{
Grupa określana mianem young adults znajduje się w kręgu zainteresowań twórców od lat 30.-40. XX wieku (Cart, 1996/2017, s. 3-21). W odniesieniu do kina i telewizji okresem niezwykle płodnym w kierowane do tej grupy dzieła był przełom lat 90. i 2000., kiedy to na ekranach pojawiły się produkcje zawierające indywidualistyczne wątki związane z poszukiwaniem przez młodych ludzi swojego miejsca w świecie, np. filmy Orbitowanie bez cukru (DeVito, Shamberg, Stiller, 1996), Zakochana złośnica (Lazar, Junger, 1999) czy dylogia, na którą składają się Pamiętnik księżniczki (Houston, Chase, Iscovich, Marshall, 2011) i Pamiętnik księżniczki 2. Królewskie zaręczyny (Houston, Chase, Marshall 2004). Jednakże w ostatnich latach popularność zdobyły inne, dydaktyczne opowieści: poruszające problem tego, jak bezpiecznie funkcjonować w grupie rówieśniczej i najbliższym otoczeniu, by wymienić seriale Stranger Things (Duffer, Duffer, 2016- ) i 13 powodów (Yorkey, Son, 2017- ). Przywołane przykłady stanowią oczywiście jedynie wycinek z całego spektrum tytułów i poruszanych w nich problemów.
} 
w rozprawie Małgorzaty Kozubek (2016) Filmoterapia. Teoria i praktyka. Autorka zwraca uwagę na istotną rolę procesu projekcji-identyfikacji i jego praktyczne wykorzystanie w zajęciach terapeutycznych. Według badaczki, „projekcja-identyfikacja [...] jest częścią reakcji emocjonalnych i poznawczych widza, stanowi czynnik umożliwiający i uaktywniający proces filmoterapeutyczny" (s. 14). Potwierdza to sens zastosowania jako środka pomocniczego takiego utworu narracyjnego, który dla odbiorcy będzie bardziej realistyczny niż projekcje wizualne pozbawione fabuły. Tymczasem to właśnie one - o czym wspomina Kozubek (s. 15) - są powszechniej wykorzystywane w arteterapii. Wprowadzenie do procesu terapeutycznego bohatera lub bohaterki, z którym można się utożsamić, pozwala widzom przenieść na fikcyjną postać swoje doświadczenia i jednocześnie poznać własną sytuację z perspektywy obserwatora, nie uczestnika, odnieść się do przebytych traum ${ }^{4}$. W omawianym przypadku hipotetyczni odbiorcy serialu Ania, nie Anna razem z bohaterką stawiają kilka kluczowych dla rozwoju tożsamości pytań, a potem wspólnie z nią odnajdują na nie odpowiedzi

Opisany przez Kozubek (2016, s. 13) mechanizm przeniesienia doświadczeń własnej traumy to forma terapii wspomagającej, sprawdzająca się w sytuacji, w której urazy psychiczne nie nakładają się na siebie. Z uwagi na wspomniane wcześniej $\mathrm{w}$ artykule wątki dotyczące postaci skrzywdzonej dziewczynki, serial, jak sądzę, nie nadaje się do filmoterapii z wychowankami współczesnych domów dziecka - dla nich poziom ukazanej traumy byłby najpewniej zbyt wysoki. Są to bowiem osoby nieraz wielokrotnie odrzucone, a praca $\mathrm{z}$ nimi z zastosowaniem omawianego programu niesie ryzyko pogorszenia ich stanu psychicznego. Dlatego też wykorzystanie analizowanego tekstu kultury może w ich przypadku przynieść więcej negatywnych niż pozytywnych skutków.

Poszczególne elementy Ani, nie Anny posiadają jednak potencjał, który można wykorzystać $\mathrm{w}$ pracy $\mathrm{z}$ grupa rówieśniczą, np. na zajęciach poświęconych kryzysom dotyczącym okresu dojrzewania, związanym z problematyką kształtowania się własnej tożsamości, przemocy rówieśniczej czy fizycznych aspektów adolescencji, które to kwestie porusza serial Walley-Beckett (Oczko, Nastulczyk, Powieśnik, 2018, s. 264). W adaptacji wątki związane z tymi kryzysami początkowo pojawiają się jako bariery uniemożliwiające głównej bohaterce stabilne funkcjonowanie. Z czasem jednak to właśnie owe przeszkody uczą ją skutecznego wychodzenia z sytuacji kryzysowych.

4 Jako traumy rozumiem tutaj - w odniesieniu do osoby niedorosłej - następstwa urazów psychicznych, „przejawiające się w różnych obszarach funkcjonowania dziecka, charakteryzujące się odmienną głębokością i stopniem nasilenia” (Sikorska, 2014, s. 59). 


\section{Kim jestem?}

Osoba zapytana o to, kim jest, w pierwszej kolejności przedstawi się zazwyczaj swoim imieniem i nazwiskiem. Nadawanie i posiadanie imienia to najprostsza forma określania tożsamości. Za imieniem stoi noszący je człowiek, posiadający określone cechy charakteru, osobowość, historię oraz marzenia, a zaakceptowanie swojego imienia to ważny etap w procesie przyjmowania istniejącej tożsamości i odnajdowania się w niej. W serialu Ania, nie Anna zapytana o imię tytułowa bohaterka (Amybeth McNulty) odpowiada, że nie ma ono znaczenia - dziewczynka sądzi, że nie pozostanie bowiem na Zielonym Wzgórzu na tyle długo, by Maryla (Geraldine James) mogła je zapamiętać, dlatego prosi o nazywanie siebie Kordelią (Walley-Beckett, Caro, 2017). Widz dowiaduje się później, że Kordelia to alter ego protagonistki, z którym Ania identyfikuje się w momencie kryzysu. Owo alter ego dziewczynki nie wytrzymuje wszakże zderzenia z pragmatycznym racjonalizmem Maryli. Stąd też Ania pozostaje Anią, lecz jednocześnie nadal stara się podkreślić własną podmiotowość, tym razem - poprzez określony sposób wymawiania swego imienia (do tego wątku odwołuje się tytuł serialu). Co istotne, Maryla - mimo pewnej rezerwy wobec nowej podopiecznej - akceptuje ten warunek, tym samym uznając prawo Ani do jej własnej tożsamości, nawet jeśli dziewczynka wyraża ją w sposób komiczny lub dziecinny (według dorosłych).

Fabularnie problem imienia i autoidentyfikacji otwiera wątek (kolejnego) odrzucenia dziecka: Maryla podczas pierwszego spotkania decyduje się odesłać Anię do sierocińca. Po interwencji Mateusza (R. H. Thomson) dziewczynka wraca na Zielone Wzgórze, gdzie pani Cuthbert ją przeprasza, a także pyta, czy nadal chce zostać w Avonlea (Walley-Beckett, Shaver, 2017). Pozostawienie wyboru wskazuje na zrozumienie potrzeby samostanowienia podopiecznej. Rodzina odprawia swoisty rytuał, celebrując pojawienie się nowej członkini Ania nie tylko może spróbować malinowej nalewki „na specjalne okazje”, lecz przede wszystkim podpisuje się w rodzinnej kronice, używając nazwiska Shirley-Cuthbert (Walley-Beckett, Shaver, 2017). Wydarzenie to nadaje jej stabilną tożsamość i buduje silną, trudną do zerwania więź z nowym domem, która jest jednym z warunków sprzyjających wykształceniu się trwałego obrazu własnego „ja” (Liberska, 2008, s. 49). Zielone Wzgórze staje się dla Ani domem nie tylko w znaczeniu fizycznym, lecz także społecznym - za sprawą prośby Maryli i Mateusza o przyjęcie ich nazwiska, który to wątek nie pojawił się w powieściowym oryginale. 


\section{Z kim jestem?}

Jeszcze przed oficjalną adopcją Ani przez Cuthbertów widz może obserwować, jak dziewczynka odbierana jest przez otoczenie. Nie jest to łatwa relacja. Avonlea to niewielka osada, gdzie pojawienie się kilkunastolatki w domu rodzeństwa „odludków” traktowane jest jako ogromna sensacja. Początkowo czujność widza zostaje uśpiona, ponieważ narracja skupia się - ze zrozumiałych względów - na perspektywie Ani, Mateusza i Maryli, jednak pierwsza, pełna uprzedzeń reakcja pozostałych rodzin mieszkających w miasteczku skłania ku refleksji, że asymilacja w nowym środowisku nie będzie dla bohaterki bezproblemowa.

Ania bez wątpienia ma ogromną potrzebę współtworzenia wspólnoty, jej dotychczasowe doświadczenie z otoczeniem opierało się bowiem na byciu ofiarą w relacji przemocy i dominacji. Dlatego wizja rozpoczęcia nauki w gronie nowych koleżanek otwiera przed nią zupełnie nową perspektywę. Wyobraźnia dziewczynki jest pobudzona do tego stopnia, że w trakcie drogi do szkoły przeprowadza wyimaginowane dialogi ze swoimi koleżankami, od powitania i pierwszych grzecznościowych uwag na temat ubioru, poprzez rozmowy o Avonlea i historiach innych dziewczynek, aż po dywagacje o poezji i marzeniach (Walley-Beckett, Goldbacher, 2017). Omawiana scena ukazana jest za pomocą zbliżeń kamery - taki intymny sposób realizacji filmowej ma potencjał, by wzbudzić w widzu sympatię wobec przerysowanego zachowania głównej bohaterki. Inaczej zmontowana jest scena, w której Ania rzeczywiście spotyka się po raz pierwszy z nowymi koleżankami i kolegami - muzyka milknie, obraz staje się statyczny, kamera unika zbliżeń, a gra światła sprawia, że pomieszczenie (klasa szkolna) wydaje się zakurzone, co kontrastuje z wywołanym w poprzednich ujęciach euforycznym nastrojem dziewczynki (Walley-Beckett, Goldbacher, 2017).

Przewodniczką Ani po skomplikowanym świecie szkolnych relacji zostaje Diana Barry (Dalila Bela). Wyjaśnia, kto z kim siedzi; zdradza, że chłopców się nie lubi; tłumaczy trudne zasady rządzące spożywaniem szkolnego posiłku podczas przerwy (Walley-Beckett, Goldbacher, 2017). Dziewczynki z klasy nie okazują się materiałem na najbliższe przyjaciółki, z którymi Ania mogłaby godzinami rozmawiać o poezji. Ruby (Kyla Matthews) i Tillie (Glenna Walters) nie interesują się literaturą, a Józia (Miranda McKeon) traktuje Anię z widoczną pogardą - podczas każdej rozmowy podkreśla jej odmienne pochodzenie. Zarysowany w szkolnej sali konflikt, opierający się na opozycji „swój” - „obcy”, jeszcze przed pierwszą lekcją nabiera kolorytu i staje się powodem wykluczenia nowej mieszkanki Avonlea ze szkolnej społeczności. Kiedy Diana odciąga Anię na bok, koleżanki zaczynają komentować zachowanie protagonistki, natomiast brat jednej z nich kilkukrotnie obraża tytułową bohaterkę zwrotami 
nawiązującymi do wyrażenia underdog, oznaczającego m.in. osobę o niskim statusie społecznym (Walley-Beckett, Goldbacher, 2017). Inteligencja dziewczynki, jej górnolotny sposób wyrażania się oraz prosty strój nie polepszają sytuacji, ponieważ z ich powodu Ania jeszcze bardziej wyróżnia się na tle rówieśników. Z perspektywy osoby, która nie musi zawalczyć o swoje miejsce, cechy te nie są oczywiście niczym deprecjonującym. Trzeba jednak pamiętać, że Ania pojawia się w szkole nie tylko po raz pierwszy, lecz także z głową pełną marzeń o ciepłym, dziewczęcym kręgu zaufania. Socjalizacyjna funkcja szkoły odgrywa istotną rolę w procesie kształtowania się pozytywnego obrazu samego siebie (Liberska, 2008, s. 47), lecz mimo to w serialu - a, jak można wywnioskować nawet na podstawie pobieżnej obserwacji, $\mathrm{w}$ nie mniejszym stopniu również w otaczającej nas rzeczywistości - szkoła staje się areną walki o pozycję społeczną. Podopieczna Cuthbertów wkracza na ową arenę w momencie, kiedy uczniowie w Avonlea ukształtowali już klasową hierarchię. Widz, podobnie jak Ania, tego układu sił nie zna; bohaterka nie zdaje sobie nawet sprawy z jego istnienia. Z retrospekcji odbiorca dowiaduje się, że była ona ofiarą bullyingu w sierocińcu, dlatego też chłodne czy wręcz niemiłe przyjęcie przez rówieśników przywołuje kolejne traumatyczne wspomnienia. Dziewczynka szybko zaczyna zdawać sobie sprawę z konieczności przystosowania się do nowych warunków, czego dowodem jest zdjęcie z kapelusza wianka z polnych kwiatów uplecionego w drodze do szkoły. Diana próbuje być dla Ani oparciem: strofuje Józię, kiedy ta po raz kolejny wypomina Ani pochodzenie, jako jedyna okazuje jej współczucie podczas opowieści o przemocy seksualnej w domu państwa Hammondów. Jednakże, mimo ogromnych pokładów empatii, dziewczynka wydaje się rozdarta pomiędzy koniecznością okazania wsparcia przyjaciółce a próbą zachowania własnej pozycji w szkole oraz wśród koleżanek.

Nonkonformistyczną postawę wobec Ani przyjmuje także Gilbert Blythe (Lucas Jade Zumann). Pojawia się on w życiu protagonistki w trudnej emocjonalnie, przerażającej scenie. W lesie, podczas drogi do szkoły, Ania spotyka jednego ze szkolnych adwersarzy, który stosuje względem niej przemoc fizyczną i psychiczną. Groźną sytuację przerywa Gilbert, nie pozwalając na nękanie koleżanki (Walley-Beckett, Goldbacher, 2017). Bohater zostaje przedstawiony jako bardzo miły chłopiec, jedyny, którego w świecie szkolnego konfliktu warto lubić. I rzeczywiście: podobnie jak Diana, jest to postać empatyczna i wrażliwa, chociaż jego sympatia przysparza Ani kolejnych kłopotów - dziewczynki z klasy zaczynają postrzegać ją jako konkurentkę w walce o zainteresowanie chłopców. Podkreśleniu więzi między Anią a Gilbertem służy również to, że oboje są spoza Avonlea - ona naturalnie jest obca w zgranym środowisku szkolnym, on w miasteczku jest rzadkim "gościem” ze względu na chorobę 
ojca. Oboje są też nieprzeciętnie - w porównaniu z rówieśnikami - oczytani i inteligentni. Jednocześnie społeczny odbiór obojga diametralnie się różni. Gilbertowi wolno więcej w oczach pozostałych uczniów, a o to, że uparcie próbuje przekonać Anię do siebie, koleżanki mają pretensje tylko do niej. Również nauczyciel traktuje go z nieporównywalnie większą pobłażliwością: kiedy Ania uderza Gilberta tabliczką, prowadzący lekcję nie przyjmuje do wiadomości, że chłopak sprowokował sytuację, ciągnąc bohaterkę za włosy, skutkiem czego ukarana zostaje tylko Ania (Walley-Beckett, Goldbacher, 2017).

Ania i Maryla (oddzielnie, ale w tym samym czasie) odkrywają trudności związane z przynależnością do grupy. Pojawienie się nastolatki na Zielonym Wzgórzu zostaje odnotowane w całym Avonlea. Fakt ten nie uchodzi również uwadze koła „postępowych” matek, nieformalnej grupy kobiet, którym (przynajmniej deklaratywnie) zależy na nowoczesnej edukacji córek. Maryla, jako opiekunka Ani, zostaje zaproszona do wzięcia udziału w spotkaniu koła, ponieważ - jak zauważa w rozmowie z Mateuszem - ona i jej brat są teraz rodzicami. Kobieta, podobnie jak Ania w szkole, próbuje realizować społeczne oczekiwania związane z nową rolą, lecz nie odnajduje się w nieznanych jej dotąd realiach. Częściowo podziela przekonania pozostałych członkiń grupy: uważa, że dobre wykształcenie jest podstawą do zdobycia pracy, a zatem osiągnięcia niezależności ${ }^{5}$. Jednakże kiedy postępowe matki oskarżają trzynastoletnią Anię o sianie zgorszenia opowieściami o przemocy seksualnej w jednej z poprzednich rodzin zastępczych, Maryla zdecydowanie potępia "postępowe” rodzicielstwo pozbawione współczucia dla skrzywdzonego dziecka i tabuizujące przemoc seksualną wobec dzieci (Walley-Beckett, Goldbacher, 2017).

W najbliższym otoczeniu Ani pojawiają się też inne bohaterki, za pomocą których Walley-Beckett, twórczyni serialu, komentuje zakorzeniony w ówczesnych realiach stosunek ogółu do roli kobiety. Jedna z owych postaci, starsza od głównej bohaterki o kilka lat Prissy Andrews (Ella Jonas Farlinger), po zakończeniu szkoły staje przed dylematem: zdecydować się na ślub czy kontynuować

5 Potrzeba niezależności finansowej kobiety jest jednym $\mathrm{z}$ najbardziej - tym razem realnie - postępowych wątków, które w swoich powieściach umieściła Lucy Maud Montgomery. Wykształcenie umożliwiające pracę zarobkową pojawia się nie tylko w sadze o Ani Shirley, lecz także w znacznie bardziej melancholijnym cyklu o Emilce ze Srebrnego Nowiu. Początek XX wieku, gdy opublikowano Anię z Zielonego Wzgórza oraz lata 20. tego stulecia, kiedy miało miejsce pierwsze wydanie Emilki ze Srebrnego Nowiu (Montgomery, 1923/2015), to czas, w którym żeńskie ruchy emancypacyjne przybierają na sile, a ich postulaty dotyczące m.in. pracy zarobkowej kobiet zaczynają wchodzić w życie. Nie bez znaczenia w tym kontekście pozostaje też fakt, że ciężar utrzymania rodziny miał spoczywać na barkach autorki (Oczko, 2013, s. 43; na temat feminizujących wątków samych powieści zob. s. 52-60). 
edukację. Ostatecznie wybiera tę drugą możliwość, gdyż, jak stwierdza, na ślub jest jeszcze za młoda. Dzieje się to przy dezaprobacie wspomnianej już grupy „postępowych” kobiet, na której czele stoi matka dziewczyny (Edwards, Tapping, 2018). Ta sama grupa gorąco sprzeciwia się obecności w szkole nowej nauczycielki, która szybko staje się symbolem feministycznego „zgorszenia”. Muriel Stacy (Joanna Douglas) jest wykształconą kobietą, utrzymującą się samodzielnie, nie ma męża i jeździ w spodniach na zasilanym elektrycznie rowerze. Podobnie jak wcześniej Ania, zostaje niechcianą Inną w konserwatywnym miasteczku, dlatego też mieszkańcy podejmują (nieudaną) próbę „utemperowania" jej niepokornej postawy (Walley-Beckett, Fox, 2018) .

\section{Jaka jestem?}

Rozpoczęcie nauki w szkole jest dla Ani kolejnym trudnym doświadczeniem $\mathrm{w}$ niewielkim odstępie czasu. Bolesne zderzenie $\mathrm{z}$ rzeczywistością i odtrącenie przez grupę rówieśniczą owocuje następnym kryzysem. Świeże wspomnienie psychicznej przemocy ze strony innych dzieci przywołuje obrazy z dawniejszej przeszłości protagonistki - z pobytu w sierocińcu, gdzie rówieśnicy straszyli nadwrażliwą koleżankę martwymi zwierzętami i kpili z jej marzeń o domu (Fahey, Bailey, 2018). W obu przypadkach Ania, próbując wyjść z kryzysu, odnajdywała nowe wyobraźniowe „przyjaciółki”. W książkowym oryginale było to echo mieszkające w starym zegarze oraz świetlne refleksy na szkle. W serialu protagonistka znowu przywołuje alter ego. Kordelia pojawia się w śpiewanych przez nią rymowankach, a swojemu odbiciu w szklanej gablocie nastolatka nadaje imię Kathy (Walley-Beckett, Evans, 2017). Sceny, w których bohaterka rozmawia na Zielonym Wzgórzu z własnym odbiciem, opatrzone zostały niepokojącym podkładem muzycznym. Ujawniają one, że dziewczynka czuje się niezrozumiana i odrzucona nawet przez najbliższych.

Chociaż Ani udało się zbudować bliską więź z Marylą i Mateuszem, nie są oni w stanie pojąć jej lęku przed kolejnymi drwinami czekającymi na nią w szkole. Ania na czas lekcji ucieka do lasu, gdzie w szałasie czyta książki i recytuje wiersze w gronie kolejnych wyobrażonych przyjaciół. Bohaterka boryka się z dysonansem wynikającym z jej własnego obrazu samej siebie oraz tego, jak odbierana jest przez otoczenie. Koledzy i koleżanki nie akceptują dziewczyny (Walley-Beckett, Goldbacher, 2017), Maryla zarzuca jej chorobliwą skłonność do kłamstwa (Walley-Beckett, Evans, 2017). Ksiądz, wezwany na pomoc przez religijnych opiekunów, widzi w Ani wyłącznie materiał na żonę i matkę, które to role całkowicie definiowałyby jej miejsce w świecie (Walley-Beckett, 
Evans, 2017). Ona sama natomiast postrzega siebie jako wrażliwą osobę obdarzoną bogatym życiem wewnętrznym, której zdarza się przemilczeć prawdę, by nie zranić innych. Również matka Diany (Helen Johns) w przyjaciółce córki dostrzega zagrożenie. W wyniku pomyłki w trakcie eleganckiego podwieczorku organizowanego przez Anię na stole zamiast soku malinowego pojawia się wino porzeczkowe. Kompletnie nieświadome tego faktu dziewczynki wypijają całą butelkę, a pani Barry zastaje je w momencie, kiedy upojone alkoholem udają księżniczki w pokoju Ani. Matka Diany natychmiast zabiera córkę z Zielonego Wzgórza i zabrania przyjaciółkom kontaktu, a Ania postrzegana jest przez mieszkańców Avonlea jako dziecko złe i zdemoralizowane, celowo siejące zgorszenie (Walley-Beckett, Rozema, 2017).

Znaczącym wydarzeniem w życiu osady okazuje się pożar, który wybucha w jednym $z$ domów. Na ratunek sąsiadom wyruszają mieszkańcy Zielonego Wzgórza. Ania, jako jedna z niewielu osób, zachowuje zdrowy rozsądek i, korzystając z wiedzy wyniesionej z pobytu w sierocińcu, bezinteresownie ocala cudzy dobytek (Walley-Beckett, Evans, 2017). Innym razem, kiedy podczas nieobecności dorosłych mieszkańców miasteczka najmłodsze dziecko państwa Barrych nagle zaczyna się dusić z powodu krupu, pozbawiona jakiejkolwiek możliwości działania Diana udaje się po pomoc na Zielone Wzgórze. Ania i w tej sytuacji przypomina sobie, co musiała robić, kiedy dzieci w rodzinie zastępczej chorowały, dzięki czemu rozpoznaje krup i ratuje dziewczynkę przed uduszeniem się (Walley-Beckett, Fox, 2017). Bohaterka wychodzi z niemal wszystkich poważnych kryzysów stojących jej na drodze do zbudowania pozytywnego obrazu samej siebie. Po zaspokojeniu prymarnej potrzeby bezpieczeństwa - znalezieniu bezpiecznego domu i przyjęciu do rodziny - coraz lepiej radzi sobie z trudnymi sytuacjami. Co więcej, w ich przezwyciężaniu wykorzystuje wiedzę i umiejętności, które zdobyła w wyniku wydarzeń do tej pory odbieranych przez nią wyłącznie jako negatywne. Otoczenie zaczyna widzieć w niej inteligentną i rezolutną osobę, a sama Ania rewaluuje dotychczasowe doświadczenia i przez ich pryzmat postrzega siebie jako wartościową jednostkę, dzięki czemu łatwiej odnajduje się w nowym środowisku (Liberska, 2008, s. 48).

\section{Kim się staję?}

Urazy psychiczne, z którymi protagonistka mierzyła się w przeszłości, wyraźnie odcisnęły się na kształtującej się osobowości nastolatki, co poskutkowało głęboką wrażliwością w reagowaniu na otaczającą rzeczywistość. Umiejętność 
racjonalnego myślenia oraz szerokie spektrum życiowych doświadczeń umożliwiają dziewczynie przepracowanie dotychczasowych traum. Kiedy Ania ucieka z sierocińca po początkowym odrzuceniu przez Marylę, Mateuszowi udaje się odnaleźć ją na dworcu. Bohaterka nie chce z nim rozmawiać o powrocie na Zielone Wzgórze do momentu, w którym Mateusz nazywa ją córką - wtedy ma poczucie, że przestała być sierotą, spełnia się jej marzenie o byciu „czyjąś” (Walley-Beckett, Shaver, 2017). Po pożarze uczęszczająca wraz z Anią do szkoły Ruby zatrzymuje się przez jakiś czas na Zielonym Wzgórzu. Tam, niewystawione na presję oceniającego środowiska, dziewczynki zbliżają się do siebie (Walley-Beckett, Evans, 2017). Natomiast po uratowaniu życia Minnie Barry (Ryan Kiera Armstrong) główna bohaterka zyskuje aprobatę rodziców Diany, dzięki czemu czuje się jej pełnoprawną przyjaciółką (Walley-Beckett, Fox, 2017). Ania Shirley na oczach widza zaczyna przynależeć również do społeczności Avonlea. Przede wszystkim jednak, w wyniku pozytywnego rozwiązania sytuacji kryzysowych, staje się odważną i pewną siebie dziewczyną.

Nastolatka w serialu Walley-Beckett dorasta nie tylko społecznie i emocjonalnie. Istotny jest też wymiar jej dojrzewania fizycznego, zainicjowany pierwszą miesiączką, czemu poświęcony został cały odcinek (Walley-Beckett, Rozema, 2017). Wątek ten nie pojawia się w książkowym oryginale. Dopiero w 2017 roku, ponad sto lat po wydaniu drukiem pierwszego egzemplarza powieści o dorastającej dziewczynie, w serialu o wydźwięku feminizującym można było odtabuizować zagadnienie menstruacji. Wydarzenie nie wykracza jednak poza domenę kobiet. Gdy Maryla wpada na Anię piorącą nad ranem zakrwawioną pościel, dziewczynka z przerażeniem i charakterystyczną dla niej przesadą krzyczy: „Przepraszam! Postawiłaś na złego konia! [...] Jeśli zechcesz wysłać mnie do szpitala na resztę moich dni, całkowicie zrozumiem! [...] Czy możesz zasadzić różowe róże na moim grobie?” (Walley-Beckett, Rozema, 2017); w kuchni pojawia się również Mateusz, który reaguje zmieszaniem i zostawia kobiety same. Maryla próbuje uzmysłowić podopiecznej normalność i naturalność okresu, lecz próby te przynoszą początkowo całkowicie odmienny efekt. Reakcje organizmu związane z menstruacją są dla dziewczyny tak dokuczliwe, że nie umie się z tym faktem pogodzić. Ania nie posiada świadomości swojego ciała, nie zna jego dokładnej budowy ani procesów fizjologicznych, jakie w nim zachodzą.

Oczywiście w opowieści, której akcja rozgrywa się pod koniec XIX wie$\mathrm{ku}$, brak rzetelnej edukacji dotyczącej dojrzewania zarówno dziewcząt, jak i chłopców nie jest niczym zaskakującym. Jednakże wątek ten nie pojawił się ani w książkowym oryginale, ani w ekranizacji telewizyjnej z Megan Follows w roli Ani (McDougall, Sullivan, 1985). Współczesna reinterpretacja jest 
pierwszą, w której Ania przechodzi dojrzewanie tak, jak wszystkie dziewczęta w zbliżonym do niej wieku. Mierzy się z wahaniami nastrojów i złym samopoczuciem. Co ważne, odcinek nie ma komediowego wymiaru. Próbuje się w nim przedstawić moment przejścia od dziewczynki w kobietę w sposób realistyczny i estetyczny zarazem, pokazując go z punktu widzenia różnych bohaterek.

Maryla i jej sąsiadka wymieniają się wspomnieniami na temat ich własnych doświadczeń związanych z kobiecością i seksualnością. Ania także dzieli się faktem wystąpienia pierwszego krwawienia z koleżankami, które - jak się okazuje - w większości mają je już za sobą. Dziewczęta, podobnie jak wcześniej Diana, przewodniczą Ani po świecie społecznych konwenansów dotyczących menstruacji: jest to tajemnica, chłopcy nie powinni o tym wiedzieć, należy dobrze się zabezpieczać przed „wypadkiem” (przeciekaniem krwi na ubranie), ponieważ potencjalna plama będzie powodem do wstydu. Z obawy przed ostatnim Ania nie jest w stanie uczestniczyć w lekcjach tak aktywnie, jak dotychczas. W serialu wyraźnie zaznaczono jednak, że rozkojarzenie wynika nie z przyczyn biologicznych, ale jest efektem strachu przed publicznym upokorzeniem w sytuacji, kiedy kobieta doprowadzi do ubrudzenia odzieży "tą" krwią, kulturowo postrzeganą jako wyjątkowo nieczysta. Chociaż w serialu okres nadal funkcjonuje jako temat, o którym niekoniecznie powinno się rozmawiać, jego obecność na ekranie przełamuje tabu, jakimi obłożone są w kulturze krew menstruacyjna i sam okres (Yuko, 2017).

\section{Zakończenie}

Powieść Lucy Maud Montgomery z wielu powodów może być dzisiaj odbierana jako anachroniczna, nie tylko ze względu na fabularny czas akcji, lecz także z powodu użytego przez autorkę języka. Adaptacja, której podjęła się Moira Walley-Becket, ze względu na możliwość aktualizacji problematyki utworu pozwala zwrócić uwagę na to, że rola, którą pierwotnie odgrywało dzieło literackie, i znaczenie, które może dzisiaj mieć serial, są podobne. Oba teksty kultury, posługując się różnymi formami narracji, umożliwiają budowę pozytywnego girl-empowermentu w języku dostosowanym do ich grup odbiorców.

Ania Shirley w świadomości pokoleń kobiet funkcjonuje jako towarzyszka dorastania oraz pierwsza „przyjaciółka”. Sposób wykreowania tej postaci w serialu Ania, nie Anna umożliwia nawiązanie więzi emocjonalnej ułatwiającej proces projekcji-identyfikacji (Kozubek, 2016, s. 107). Doświadczenie rówieśniczej przemocy, zwłaszcza w zupełnie nowym środowisku; odrzucenie 
ze względu na inność i „nieprzystawalność” do otoczenia; konflikt wewnętrzny wywołany chęcią przynależności do grupy oraz jednoczesną potrzebą zachowania własnej niezależności; wreszcie brak znajomości własnej fizjologii w czasie jej intensywnych zmian - problemy te są nieobce również współczesnej młodzieży. Pozytywne rozwiązywanie kolejnych konfliktów stojących na drodze rozwoju głównej bohaterki oraz konstruowanie w wyniku tych działań stabilnej tożsamości, pewności siebie i poczucia własnej wartości może prowokować potencjalnego widza do rozmowy o jego własnych doświadczeniach związanych z problematycznym okresem dojrzewania oraz zachęcić go do ich satysfakcjonującego przepracowania. Serial ma zatem, co warto potwórzyć, potencjał filmoterapeutyczny.

\section{Bibliografia}

Cart, M. (2017). Young adult literature: From romance to realism. Chicago, IL: American Library Association. (wyd. oryg. 1996).

CBC. (2016). Anne of Green Gables set for new life on CBC-TV. Pobrane z: https:// www.cbc.ca/news/entertainment/anne-of-green-gables-cbc-tv-1.3394073.

DeVito, D., Shamberg, M. (prod.), Stiller, B. (reż.). (2015). Reality bites [Orbitowanie bez cukru] [film]. USA: Universal Pictures.

Duffer, M., Duffer, R. (prod.). (2016- ). Stranger things [serial telewizyjny]. Los Gatos, CA: Netflix.

Edwards, S. (scen. i reż.), Tapping, A. (reż.). (2018). Struggling against the perception of facts [Odmawiać dostrzegania faktów] [odcinek serialu telewizyjnego]. W: M. Walley-Beckett, Anne with an E [Ania, nie Anna]. Ottawa, Los Gatos, CA: CBC, Netflix.

Fahey A. (scen. i reż.), Bailey, N. (reż.). (2018). The determining acts of her life [Decydujące w jej życiu postepki] [odcinek serialu telewizyjnego]. W: M. WalleyBeckett, Anne with an E [Ania, nie Anna]. Ottawa, Los Gatos, CA: CBC, Netflix.

Has-Tokarz, A. (2006/2007). Między słowem a obrazem. Afiliacje literatury i filmu (perspektywa komparatystyczna). Folia Bibliologica, 48-49, 87-113.

Houston, W., Chase, D. M. (prod.), Marshall, G. (reż.). (2004). The princess diaries 2: Royal engagement [Pamiętnik księżniczki 2. Królewskie zaręczyny] [film]. USA: Buena Vista Pictures.

Houston, W., Chase, D. M., Iscovich, M. (prod.), Marshall, G. (reż). (2001). The princess diaries [Pamiętnik księżniczki] [film]. USA: Buena Vista Pictures.

Kozubek, M. (2016). Filmoterapia. Teoria i praktyka. Gdańsk: Słowo/Obraz Terytoria. Lazar, A. (prod.), Junger, G. (reż.). (1999). 10 things I hate about you [Zakochana złośnica] [film]. USA: Buena Vista Pictures. 
Liberska, H. (2008). Tożsamość młodzieży i jej orientacja temporalna - ogólny model rozwoju. W: B. Zimoń-Dubowik, M. Gamian-Wilk (red.), Oblicza tożsamości. Perspektywa interdyscyplinarna (s. 47-61). Wrocław: WN DSW.

McDougall, I., Sullivan, K. (prod.). (1985). Anne of Green Gables [Ania z Zielonego Wzgórza] [serial telewizyjny]. Ottawa: CBC.

Montgomery, L. M. (2014). Ania z Zielonego Wzgórza (wyd. 2. popr., P. Beręsewicz, tłum.). Kraków: Skrzat. (wyd. oryg. 1908).

Montgomery, L. M. (2015). Emilka ze Srebrnego Nowiu (R. Grzybowska, tłum.). Warszawa: Wydawnictwo Literackie. (wyd. oryg. 1923).

Oczko, P. (2013). Anna z domu o zielonym dachu. O cyklu powieściowym Lucy Maud Montgomery. Teksty Drugie, 5, 42-61.

Oczko, P., Nastulczyk, T., Powieśnik, D. (2018). Na szwedzkim tropie Ani z Zielonego Wzgórza. O przekładzie Rozalii Bernsteinowej. Ruch Literacki, 3(348), 261-280. https://www.doi.org/10.24425/122705.

Sikorska, I. (2014). Dziecięca trauma - psychologiczne konsekwencje dla dalszego rozwoju. Sztuka Leczenia, 3-4, 55-70.

Walley-Beckett, M. (prod.). (2017- ). Anne with an E [Ania, nie Anna] [serial telewizyjny]. Ottawa, Los Gatos, CA: CBC, Netflix.

Walley-Beckett, M. (scen.), Caro, N. (reż.). (2017). Your will shall decide your destiny [Niech twoja wola decyduje o twoim losie] [odcinek serialu telewizyjnego]. W: M. Walley-Beckett, Anne with an E [Ania, nie Anna]. Ottawa, Los Gatos, CA: CBC, Netflix.

Walley-Beckett, M. (scen.), Evans, D. (reż.). (2017). An inward treasure is born [Skarb w głębi duszy] [odcinek serialu telewizyjnego]. W: M. Walley-Beckett, Anne with an $E$ [Ania, nie Anna]. Ottawa, Los Gatos, CA: CBC, Netflix.

Walley-Beckett, M. (scen.), Fox, P. (reż.). (2017). Remorse is the poison of life [Wyrzuty sumienia to trucizna życia] [odcinek serialu telewizyjnego]. W: M. Walley-Beckett, Anne with an $E$ [Ania, nie Anna]. Ottawa, Los Gatos, CA: CBC, Netflix.

Walley-Beckett, M. (scen.), Fox, P. (reż.). (2018). What we have been makes us what we are [Bo dzisiaj tym jesteśmy, czym byliśmy wczoraj] [odcinek serialu telewizyjnego]. W: M. Walley-Beckett, Anne with an E [Ania, nie Anna]. Ottawa, Los Gatos, CA: CBC, Netflix.

Walley-Beckett, M. (scen.), Goldbacher, S. (reż.). (2017). But what is so headstrong as youth? [Cóż jest bardziej uparte od młodości?] [odcinek serialu telewizyjnego]. W: M. Walley-Beckett, Anne with an E [Ania, nie Anna]. Ottawa, Los Gatos, CA: CBC, Netflix.

Walley-Beckett, M. (scen.), Rozema, P. (reż.). (2017). Tightly knotted to a similar string [Nierozerwalny węzeł przyjaźni] [odcinek serialu telewizyjnego]. W: M. Walley-Beckett, Anne with an E [Ania, nie Anna]. Ottawa, Los Gatos, CA: CBC, Netflix. 
Walley-Beckett, M. (scen.), Shaver, H. (reż.). (2017). I am no bird, and no net ensnares me [Nie jestem ptakiem i żadna sieć mnie nie więzi] [odcinek serialu telewizyjnego]. W: M. Walley-Beckett, Anne with an E [Ania, nie Anna]. Ottawa, Los Gatos, CA: CBC, Netflix.

Yorkey, B., Son, D. (prod.). (2017- ). 13 reasons why [13 powodów] [serial telewizyjny]. Los Gatos, CA: Netflix.

Yuko, E. (2017, 22 maja). Why it matters that Anne With an E has a period episode. Pacific Standard. Pobrane z: https://psmag.com/social-justice/half-the-population-suffers-through-it. 